\title{
Hubungan Antara Kepekaan Humor dan Kreativitas Dengan Kematangan Emosi Siswa Kelas XI SMK Negeri 11 Semarang
}

\author{
Rahmadiyanti P W \\ Universitas Negeri Semarang, Jawa Tengah, Indonesia \\ rahmadiyanti887@gmail.com \\ Awalya \\ Universitas Negeri Semarang, Jawa Tengah, Indonesia \\ dmj.awalya@mail.unnes.ac.id
}

\begin{abstract}
Abstrak
Penelitian ini memiliki tujuan untuk mengetahui hubungan antara kepekaan humor dan kreativitas dengan kematangan emosi siswa kelas XI SMK Negeri 11 Semarang, Jawa Tengah. Permasalahan yang mendasari dari penelitian ini adalah terjadinya beberapa fenomena di SMK Negeri 11 Semarang. Fenomena-fenomena tersebut berhubungan dengan kematangan emosi. Banyak siswa yang mengalami permasalahan karena tingkat emosi mereka yang kurang matang seperti terjadinya perkelahian yang berawal dari saling mengejek sampai tidak mau masuk sekolah karena minder dengan gaya hidup teman-temannya. Metode yang digunakan dalam penelitian ini adalah metode kuantitatif yang menggunakan dua alat pengumpul data yaitu skala pikologis dan teknik wawancara. Hasil dari penelitian ini adalah terdapat hubungan positif yang signifikan antara kepekaan humor dan kreativitas dengan kematangan emosi. Hasil penelitian ini juga bermanfaat bagi guru BK agar lebih memberikan inovasi dalam penyusunan layanan BK di sekolah.
\end{abstract}

Kata kunci: kematangan emosi; kepekaan humor; kreativitas.

\section{Abstract}

This study aims to determine the relationship between humor sensitivity and creativity with the emotional maturity of class XI students of SMK Negeri 11 Semarang, Central Java. The underlying 
problem of this research is the occurrence of several phenomena in SMK Negeri 11 Semarang. These phenomena are related to emotional maturity. Many students experience problems due to their immature emotional level such as a fight that starts from mocking each other to not going to school because they are inferior to the lifestyle of their friends. The method used in this study is a quantitative method that uses two data collection tools namely the picological scale and interview techniques. The results of this study are that there is a significant relationship between humor sensitivity and creativity with emotional maturity. The results of this study are also beneficial for BK teachers to give more innovation in the preparation of $B K$ services in schools.

Keywords: emotional maturity; humor sensitivity; creativity.

\section{A. Pendahuluan}

Kematangan emosi adalah salah satu aspek dari hasil perkembangan remaja yang perlu diperhatikan. Chaplin (2011) mendefinisikan kematangan emosi adalah suatu fase tahap perkembangan emosi seseorang yang sudah mencapai tingkat kedewasaan sehingga emosinya sudah matang dan tidak lagi menunjukan pola emosional seperti anak-anak. Pernyataan tersebut ditambahkan oleh Hurlock (1994) menambahkan bahwa kematangan emosi adalah suatu kondisi perasaan yang stabil terhadap suatu obyek permasalahan sehingga ketika mengambil suatu keputusan atau bertingkah laku didasari dengan suatu pertimbangan yang matang dan suasana hati bisa lebih stabil.

Dalam kehidupan sehari-hari pencapaian kematangan emosi seorang individu sangatlah penting. Kematangan emosi pada remaja sangat diperlukan untuk memudahkan dalam pergaulan dengan teman sebayanya maupun di atas atau di bawah usianya. Kematangan emosi juga memudahkan individu untuk lebih mudah beradaptasi dengan lingkungan yang baru (Hurlock, 1999). Individu yang sudah mencapai kematangan emosional akan cenderung mampu mengambil keputusan dengan bijak. Banyak para remaja yang belum matang emosional menjadi terburu-buru dalam mengambil keputusan sehingga keputusan yang 
diambil dengan terburu-buru akan berdampak negatif untuk dirinya sendiri. Sedangkan, salah satu faktor dari kematangan emosional menurut Walgito (dalam Guswani dan Fajar, 2011) adalah memiliki sifat sabar. Individu yang sabar tidak akan terburu-buru, artinya individu yang memiliki kematangan emosional cenderung akan sabar dalam menyikapi segala sesuatu dan berpikir panjang sebelum mengambil keputusan.

Feinberg (dalam Handayani, 2008) menguraikan beberapa karakteristik mengenai seseorang yang sudah mencapai kematangan emosi salah satunya adalah mempunyai rasa humor. Menurut Hartanti dan Rahaju (dalam Parman, 2013) menjelaskan pengertian dari rasa humor atau kepekaan humor adalah suatu kemampuan individu menggunakan humor sebagai cara menyeselsaikan masalah, keterampilan menciptakan humor, kemampuan menghargai atau menanggapi humor. Orang dewasa yang memiliki rasa humor atau memiliki kepekaan humor yang tinggi merupakan bagian dari emosi yang sehat yang bisa memunculkan senyuman hangat untuk bisa menyeseuaikan diri dengan lingkungan manapun atau di lingkungan dimana dia berada.

Selain rasa humor atau kepekaan humor, karakteristik seseorang yang sudah mencapai kematangan emosi salah satunya dapat dilihat melalui tingkat kreativitas siswa. Kreativitas tidak hanya perbuatan otak saja, tetapi di dalamnya terdapat variabel emosi dan kesehatan mental. Dengan demikian dapat dikatakan kematangan emosi dapat ditunjang dengan kreativitas. Menurut Munandar (2002) salah satu tujuan memiliki kemampuan kreativitas adalah individu mampu melihat berbagai macam penyeselaian suatu masalah dari berbagai sudut pandang. Mengekspresikan pikiran-pikiran yang berbeda dari orang lain tanpa dibatasi pada hakikatnya akan mampu melahirkan berbagai macam gagasan.

Dari pembahasan diatas, peneliti ingin melakukan penelitian di SMK Negeri 11 Semarang untuk mencari jawaban dari rumusan masalah bagaimana hubungan antara kepekaan humor dan kreativitas dengan kematangan emosi siswa kelas XI SMK Negeri 11 Semarang sehinggga tujuan penelitian ini untuk mengetahui 
hubungan antara kepekaan humor dan kreativitas dengan kematangan emosi siswa kelas XI SMK Negeri 11 Semarang. Metode yang digunakan dalam penelitian ini yaitu menggunakan jenis penelitian kuantitatif kolerasional karena peneliti ingin mengetahui tentang hubungan antarvariabel yang diteliti.

Dalam penelitian ini, peneliti menggunakan jenis penelitian kuantitatif kolerasional. Menurut Arikunto (2010) jenis penelitian kuantitatif kolerasional adalah penelitian yang digunakan untuk menganalisis ada tidaknya hubungan antara dua variabel atau lebih. Peneliti menggunakan jenis penelitian kuantitatif kolerasional karena peneliti memiliki tujuan untuk mengetahui hubungan antara kepekaan humor dan kreativitas dengan kematangan emosi siswa kelas XI SMK Negeri 11 Semarang. Dalam penelitian ini menggunakan variabel kepekaan humor $\left(\mathrm{X}_{1}\right)$ dan kreativitas $\left(\mathrm{X}_{2}\right)$ sebagai variable independen atau variabel bebas dan variabel kematangan emosi $(\mathrm{Y})$ sebagai variable dependen atau variabel terikat.

Populasi dalam penelitian ini adalah siswa kelas XI SMK Negeri 11 Semarang. Jumlah siswa kelas XI SMK Negeri 11 Semarang pada tahun 2019 berjumlah 559 siswa. Teknik pengambilan sampel dalam penelitian ini menggunakan Probability Sampling dengan jenis Cluster Sampling. Dalam hal ini, populasi yang digunakan berjumlah 559 dengan taraf kesalahan 5\%, maka jumlah sampel yang digunakan berjumlah 213 siswa. Tujuan penelitian ini dapat bermanfaat bagi guru BK agar selalu memberikan inovasi setiap penyusunan layanan BK di sekolah yang bisa memasukan variabel kepekaan humor dan kreativitas untuk membantu mencapai kematangan emosi siswa.

\section{B. Pembahasan}

Dalam pembasahan ini akan diuraikan penjelaskan mengenai pokok bahasan dari penelitian ini yaitu kematangan emosi, kepekaan humor dan kreativitas. Metode penelitian juga akan dijelaskan pada bab ini. Berikut uraian dari pokok pembahasan dalam penelitian ini: 


\section{Kematangan Emosi}

\section{a. Pengertian Kematangan Emosi}

Kematangan emosi merupakan aspek penting dalam diri individu dimana individu mampu mengelola dan mengendalikan emosi tanpa harus dengan meledak-ledak. Individu yang sudah mampu mencapai kematangan emosi akan mudah beradaptasi dan diterima oleh masyarakat umum.

Menurut Hurlock (1999) kematangan emosi adalah suatu kondisi perasaan yang stabil terhadap suatu objek permasalahan sehingga sebelum mengambil suatu keputusan atau bertingkah laku didasari dengan pertimbangan yang matang dan sungguh-sungguh serta suasana hatinya juga cenderung stabil.

Menurut Katkovsky dan Gorlow (Dalam Agrippina, 2016) menjelaskan bahwa kematangan emosi adalah suatu keadaan individu dimana dia selalu berusaha mencapai emosi yang sehat dan stabil secara intrafisik maupun interpersonal

Dari beberapa pendapat diatas dapat disimpulkan yang dimaksud dengan kematangan emosi adalah kemampuan dan kesanggupan individu untuk merespon suatu stimulus dengan bentuk emosi yang baik dalam menghadapai tantangan hidup yang ringan dan berat serta mampu menyelesaikan dan mampu mengendalikan luapan emosi serta mengantisipasi secara kritis suatuasi yang dihadapi. Remaja yang memiliki kematangan yang cukup dapat membantu mereka dalam menjalin hubungan sosial yang lebih luas.

\section{b. Aspek-Aspek Kematangan Emosi}

Dalam mengetahui tingkat kematangan emosi seseorang, kita dapat melihat dari beberapa aspek kematangan emosi. Menurut Katkovsky dan Gorlow (dalam Agrippina, 2016) menguraikan mengenai aspek-aspek kematangan emsoi antara lain: 
1) Kemandirian

Aspek kemandirian yang dimaksud adalah suatu kemampuan dalam memutuskan sesuatu sesuai apa yang diinginkan serta mampu untuk mempertanggungjawabkan keputusan yang sudah dipilih.

2) Kemampuan Menerima Kenyataan

Aspek kemampuan menerima kenyataan yang dimaksud adalah individu memiliki kemampuan untuk menerima dirinya sendiri apa adanya secara utuh dan menyadari bahwa dirinya dengan orang memiliki kemampuan yang berbeda dari segi kesempatan, tingkat intelegensi dan lain sebagainya.

3) Kemampuan Beradaptasi

Aspek kemampuan beradaptasi yang dimaksud adalah individu memiiliki kemampuan dalam menerima dan menjalani adanya karakteristik-karakteristik dan situasi kondisi yang berbeda-beda.

4) Kemampuan Merespon dengan Tepat

Aspek kemampuan merespon dengan tepat artinya individu memiliki kepekaan dalam merespon kebutuhan emosi orang lain. Contohnya seseorang yang memiliki kepekaan yang tinggi, ketika melihat orang lain sedang menangis, dia akan langsung meresponnya dengan menunjukan rasa empatinya.

5) Kapasitas Untuk Seimbang

Aspek kapasitas untuk seimbang artinya individu memiliki kemampuan dalam menyeimbangkan kebutuhan emosi diri sendiri dan orang lain dengan melihat dari berbagai sudut pandang

6) Kemampuan Berempati

Aspek kemampuan berempati artinya individu memiliki kemampuan dalam merasakan apa yang dirasakan orang lain atau mampu menempatkan dirinya bagaimana perasaanya andaikata menjadi orang lain.

7) Kemampuan Menguasai Amarah 
Aspek kemampuan menguasi amarah artinya individu mampu mengetahui penyebab apa saja yang bisa menjadikan dia marah, tetapi dia juga tahu bagaimana cara mengendalikan amarahnya.

\section{c. Faktor-Faktor yang Mempengaruhi Kematangan Emosi}

Kematangan emosi setiap individu memiliki tingkat yang berbeda-beda karena berbagai faktor. Beberapa ahli sudah menjelaskan mengenai faktor-faktor kematangan emosi. M. Ali dan M. Asrosri (2012) menguraikan mengenai faktorfaktor yang mempengaruhi kematangan emosi sebagai berikut:

1) Perubahan Jasmani

Perubahan jasmani seseorang mampu mempengaruhi tingkat kematangan emosi karena pertumbuhan fisik dari anggota tubuh individu. Tingkat keseimbangan dalam pertumbuhan fisik tubuh itulah yang mempengaruhi kematangan emosi pada remaja.

2) Pola Interaksi dengan Orang Tua

Pola atau cara interaksi antara orang tua dan anak mampu mempengaruhi tingkat kematangan emosi. Pola atau cara interaksi orang tua yang menunjukan penuh kasih sayang kepada anak akan memberikan damapak yang positif kepada anak terkait dengan kematangan emosi anak.

3) Pola Interaksi dengan Teman Sebaya

Faktor pola interaksi dengan teman sebaya memiliki peran yang cukup dominan karena usia remaja merupakan usia perkenalan teman sebaya baik lawan jenis maupun sesama jenis. Pola interaksi dalam suatu hubungan pertemanan mampu saling mempengaruhi berbagai sikap, termasuk mampu mempengaruhi kematangan emosi anak. Ketika anak berada di dalam suatu hubungan pertemanan yang didominasi oleh sikap-sikap negatif seperti pemarah, maka anak kan berpeluang untuk memiliki kematangan emosi yang belum matang.

4) Pola Interaksi dengan Sekolah

Pola interaksi antara pihak sekolah dengan anak juga mampu mempengaruhi kematangan emosi anak. Ketika pihak sekolah membuat suatu 
peraturan yang tidak sesuai dengan nilai-nilai seumumnya sesuai tahap perkembangan remaja, maka anak akan cenderung menunjukan sikap penolakan yang artinya kematangan emosi anak menjadi belum matang.

5) Pandangan Luar

Cara berpikir anak dalam memandang pandangan di luar dirinya sendiri akan mempengaruhi tingkat kematangan emosi anak. Ketika anak terbiasa berpikir tentang pandangan luar yang negatif berdasarkan pikiran dia sendiri, maka akan mempengaruhi tingkat kematangan emosi yang cenderung susah untuk stabil.

\section{Kepekaan Humor}

\section{a. Pengertian Kepekaan Humor}

Kepekaan humor adalah kemampuan seseorang untuk menangkap adanya sesuatu yang lucu dari sebuah peristiwa. Menurut Thorson dan Powell (dalam Karim, dkk, 2018) menjelaskan bahwa kepekaan humor adalah kemampuan membuat humor, mengenali humor, mengapresiasi humor, menggunakan humor sebagai mekanisme coping dan untuk mencapai tujuan sosial. Senada dengan Hartanti (2002) kepekaan humor adalah kemampuan seseorang untuk menggunakan humor sebagai cara menyelesaikan suatu permasalahan, keterampilan menciptakan humor, dan kemampuan menghargai atau menanggapi humor. Dari pendapat diatas maka dapat disimpulkan bahwa kepekaan humor adalah kemampuan indiviu untuk peka dalam mengenali dan menggunakan humor dalam kehidupan sehari-hari termasuk dalam menyeselaikan suatu permasalahan.

\section{b. Aspek-Aspek Kepekaan Humor}

Tingkat kepekaan humor masing-masing orang berbeda, tetapi kepekaaan humor seseorang dapat diamati dengan melihat aspek-aspek dari kepekaan humor. Aspek-aspek dari kepekaan humor menurut Thorshon dan Powell (dalam Septiana, 2017) sebagai berikut: 
1) Kemampuan Menghasilkan Humor

Kemampuan menghasilkan humor berkaitan dengan kemampuan individu dalam menentukan ide atau gagasan maupun dalam menciptakan materi-materi humor atau hal-hal yang bersifat jenaka atau lucu dari pikiran sendiri.

2) Kemampuan Coping dengan Humor

Humor afektif untuk menolong individu menghadapi kesulitan. Kemampuan untuk melihat kemampuan humor merupakan salah satu yang dapat digunakan untuk mengatasi krisis hidup, sebagai perlindungan terhadap perubahan dan ketidaktentuan selain itu. Humor berfungsi sebagai pemeliharaan dalam diri yaitu suatu cara sehat yang dilakukan individu untuk merasakan jarak antara dirinya dengan masalah. Suatu cara menghindari diri dari masalah dan mengandung masalah dari sudut pandang yang berbeda.

3) Apresiasi Terhadap Humor

Apresiasi terhadap humor berkaitan dengan perhatian dan penghargaan individu terhadap humor atau segala sesuatu yang berhubungan dengan hal-hal yang sifatnya jenaka atau lucu.

4) Sikap Terhadap Humor

Sikap terhadap humor diartikan sebagai suatu bentuk penerimaan yang disertai tingkah laku atau perasaan, baik itu positif maupun negatif terhadap sesuatu atau humor yang tercemin dalam perasaan senang, menerima atau setuju.

\section{Kreativitas}

\section{a. Pengertian Kreativitas}

Rhodes (dalam Munandar, 2004) menyatakan bahwa definisi kreativitas dapat ditinjau dari empat aspek dengan istilah "Four P's of Creativity: Person, Prosess, Press, and Product" yaitu : 1. Pribadi (Person) adalah tindakan kreatif yang muncul dari keunikan keseluruhan kepribadian dalam interaksi dengan lingkungannya. 2. Proses (Process) yaitu langkah-langkah proses keatif yang banyak diterapkan dalam pengembangan kreativitas, meliputi tahap persiapan, inkubasi, iluminasi dan verifikasi. 3. Produk (Product) yaitu kemampuan 
menghasilkan atau menciptakan sesuatu yang baru. 4. Pendorong (Press) yaitu menekankan faktor "press" atau dorongan baik dorongan internal berupa keinginan dan hasrat untuk mencipta atau bersibuk diri secara kreatif, maupun dorongan eksternal dari lingkungan sosial dan psikologis.

\section{b. Aspek-Aspek Kreativitas}

Kreativitas memiliki beberapa aspek yang bisa dijadikan sebagai acuan untuk mengetahui tingkata kreativitas seseorang. Aspek-aspek kreativitas dari Guilford (dalam Sternberg, 1999) menguraikan ada empat aspek yaitu:

1) Kelancaran Berpikir

Kelancaran berpikir adalah suatu kemampuan untuk menhasilkan banyak ide yang keluar dari pemikiran secara cepat. Dalam kelancaran berpikir yang perlu ditetapkan adalah kuantitas bukan kualitias. Dalam kelancaran berpikir artinya juga suatu kemampuan mengeluarkan serta menguraikan ide yang muncul dalam waktu singkat.

2) Keluwesan Berpikir

Keluwesan berpikir adalah suatu kemampuan dalam mengembangkan sejumlah ide jawaban atau pertanyaan yang bervariasi melihat suatu masalah dari sudut pandang yang berbeda-beda. Individu yang memiiliki keluwesan dalam berpikir maka dia akan mampu menggunakan berbagai macam pendekatan atau cara pemikiran dalam menyelesaikan masalah. Individu akan terus mencoba berganti-ganti pendekatan pemecahan masalah sampai menemukan pendekatan pemecahan masalah yang sesuai dan tepat.

3) Elaborasi Berpikir

Elaborasi berpikir merupakan suatu kemampuan dalam menggabungkan dan menguraikan beberapa ide atau gagasan yang unik sehingga menjadi sebuah ide menarik hasil dari pengembangan berbagai gagasan.

4) Keaslian

Keaslian dalam berpikir merupakan suatu kemampuan individu dalam memunculkan dan menciptakan ide atau gagasan yang unik, dan jarang terpikirkan 
oleh orang lain. Dapat dikatakan bahwa keaslian itu memang benar-benar dari pikirannya sendiri tidak melihat atau mencontek ide orang lain.

\section{Hasil dan analisis}

Dalam metode penelitian akan diuraikan mengenai: (1) jenis penelitian, (2) variabel penelitian, (3) populasi dan sampel, (4) metode dan alat pengumpulan data dan (5) Hasil uji validitas dan Reliabilitas, (6) hasil penelitian. Berikut uraiannya yaitu:

Dalam penelitian ini, peneliti menggunakan jenis penelitian kuantitatif kolerasional. Menurut Arikunto (2010) jenis penelitian kuantitatif kolerasional adalah penelitian yang digunakan untuk menganalisis ada tidaknya hubungan antara dua variabel atau lebih. Peneliti menggunakan jenis penelitian kuantitatif kolerasional karena peneliti memiliki tujuan untuk mengetahui hubungan antara kepekaan humor dan kreativitas dengan kematangan emosi siswa kelas XI SMK Negeri 11 Semarang.

Menurut Sugiyono (2017) variabel adalah atribut atau sifat, obyek atau kegiatan dengan variasi tertentu yang ditetapkan peneliti sebagai bahan yang dipelajari secara fokus serta nanti akan ditarik kesimpulannya. Dalam penelitian ini menggunakan variabel kepekaan humor $\left(\mathrm{X}_{1}\right)$ dan kreativitas $\left(\mathrm{X}_{2}\right)$ sebagai variable independen atau variabel bebas dan variabel kematangan emosi (Y) sebagai variable dependen atau variabel terikat.

Populasi dalam penelitian ini adalah siswa kelas XI SMK Negeri 11 Semarang. Jumlah siswa kelas XI SMK Negeri 11 Semarang pada tahun 2019 berjumlah 559 siswa. Teknik pengambilan sampel dalam penelitian ini menggunakan Probability Sampling dengan jenis Cluster Sampling. Dalam hal ini, populasi yang digunakan berjumlah 559 dengan taraf kesalahan 5\%, maka jumlah sampel yang digunakan berjumlah 213 siswa.

Metode pengumpul data merupakan salah satu tahap sistematis yang harus dilalui oleh peneliti dalam memperoleh informasi penting yang dibutuhkan sebagai bahan penelitian. Dalam penelitian ini, peneliti menggunakan metode 
pengumpul data yang mengukur aspek psikologi atau biasa disebut skala psikologis. Skala psikologis digunakan untuk mengungkap keadaan psikologis dari aspek kepribadian individu. Dalam penelitian ini skala psikologi digunakan untuk mengukur kematangan emosi, kepekaan humor dan kreativitas. Sehingga alat pengumpul data yang digunakan yaitu skala kematangan emosi, skala kepekaan humor dan skala kreativitas. Berikut akan diuraikan mengenai kisi-kisi intrumen setiap skala, yaitu:

Tabel 4.1

Kisi-Kisi Instrumen Skala Kematangan Emosi

\begin{tabular}{llccc}
\hline No. & \multicolumn{1}{c}{ Indikator } & Favorable & Unfavorable & Jumlah \\
\hline & & 4,10 & 15 & 3 \\
1. & Bersikap mandiri & $2,13,27$ & $12,25,26$ & 5 \\
2. & Menerima kenyataan & & & \\
& dan realitas & 6,20 & 11 & 3 \\
3. & Adaptasi diri & 8,22 & 17 & 3 \\
4. & Respon diri yang baik. & $3,5,23,24$ & 14 & 5 \\
5. & Emosi diri seimbang. & 1,9 & 19 & 3 \\
6. & Bersikap empati & $7,21,28$ & $16,18,29,30$ & 8 \\
7. & Menguasai Amarah & 19 & 11 & 30 \\
\hline
\end{tabular}

Tabel 4.2

Kisi-Kisi Instrumen Skala Kepekaan Humor

\begin{tabular}{llccc}
\hline No. & \multicolumn{1}{c}{ Indikator } & \multicolumn{2}{c}{ Aitem } & Jumlah \\
\hline & & Favorable & Unfavorable & \\
1. & Menciptakan humor & $1,7,11,15,24$ & $4,9,19$ & 8 \\
2. & Humor sebagai coping & $3,5,13,22,25$ & $2,8,17,20$ & 9 \\
& stress & & & \\
3. & Penghargaan terhadap & $6,10,12,18$, & 14,16 & 7 \\
& humor & 26 &
\end{tabular}




\begin{tabular}{|c|c|c|c|c|}
\hline 4. & Sikap terhadap humor & $23,27,29$ & $21,28,30$ & 6 \\
\hline & Total & 18 & 12 & 30 \\
\hline
\end{tabular}

Tabel 4.3

Kisi-Kisi Instrumen Skala Kreativitas

\begin{tabular}{|c|c|c|c|c|}
\hline \multirow[t]{2}{*}{ No. } & \multirow[t]{2}{*}{ Indikator } & \multicolumn{2}{|c|}{ Aitem } & \multirow[t]{2}{*}{ Jumlah } \\
\hline & & Favorable & Unfavorable & \\
\hline 1. & $\begin{array}{l}\text { Kelancaran dalam } \\
\text { menemukan ide, } \\
\text { gagasan }\end{array}$ & $2,8,20,27$ & $5,12,30$ & 7 \\
\hline 2. & $\begin{array}{l}\text { Keluwesan berpikir } \\
\text { berbagai sudut } \\
\text { pandang }\end{array}$ & $4,7,14$ & $11,16,23,25$ & 7 \\
\hline 3. & Elaborasi ide, gagasan & $3,10,21,29$ & 6,17 & 6 \\
\hline 4. & Keaslian ide, gagasan & $1,9,15,24,26$ & $\begin{array}{c}13,18,19,22 \\
28\end{array}$ & 10 \\
\hline & Total & 16 & 14 & 30 \\
\hline
\end{tabular}

\section{e. Uji Validitas dan Reliabilitas}

Instrumen diatas dijadikan sebagai pedoman saat melakukan uji coba penelitian dengan sampel 32 siswa dari sekolahan yang berbeda dengan sampel penelitian yang sesungguhnya. Dalam perhitungan menggunakan SPSS 21 untuk uji validitas akan melihat $r_{\text {tabel }}$ dari $N=32$ yaitu 0,339. Aitem dalam instrumen dinyatakan valid ketika koefisien validitasnya $>0,339$. Berdasarkan hasil perhitungan, ada beberapa aitem yang dinyatakan tidak valid sehingga aitem tersebut harus gugur.

Nomor aitem pada skala kematangan emosi yang dinyatakan tidak valid yaitu $3,5,7,11,14$,dan 17. Nomor aitem pada skala kepekaan humor yang dinyatakan tidak valid yaitu $6,13,21$, dan 27 . Nomor aitem pada skala kreativitas 
yang dinyatakan tidak valid yaitu 12 dan 16. Selain nomor tersebut dinyatakan valid dan digunakan pada penelitian sesungguhnya.

Penelitian yang baik harus memiliki instrumen penelitian yang valid dan reliabel. Uji reliabilitas juga menggunakan bantuan SPSS 21 dimana suatu konstruk dikatakan reliabel ketika nilai $r_{\text {hitung }}>0,70$. Berikut uaian hasil uji reliabel:

Tabel 4.4

Keputusan Hasil Uji Reabilitas

\begin{tabular}{lccc}
\hline \multicolumn{1}{c}{ Instrumen } & r hitung & $\begin{array}{c}\text { r tabel pada } \\
\text { signifikansi } \\
\text { (5\%) N=34 }\end{array}$ & Keterangan \\
\hline Kematangan Emosi $(\mathrm{Y})$ & 0,842 & 0,339 & Reliabel \\
Kepekaan Humor $\left(\mathrm{X}_{1}\right)$ & 0,806 & 0,339 & Reliabel \\
Kreativitas $\left(\mathrm{X}_{2}\right)$ & 0,902 & 0,339 & Reliabel \\
\hline
\end{tabular}

Dari tabel diatas dapat kita simpulkan bahwa variabel yang diteliti yaitu variabel kepekaan humor, kreativitas dan kematangan emosi telah dinyatakan reliabel karena sudah memenuhi syarat yaitu nilai $r_{h i t u n g}$ setiap variabel lebih besar dari 0,7 .

Untuk mengetahui adanya hubungan dan seberapa besar nilai hubungan antar variabel yang diteliti, menggunakan uji analisis regresi dengan menggunakan bantuan SPPS 21. Berikut akan diuraian mengenai hasil uji analisis regresi dalam bentuk tabel:

Tabel 4.5

Hasil Uji Analisis Regresi Terhadap Kematangan Emosi

\begin{tabular}{lcccccc}
\hline \multicolumn{1}{c}{ Variabel } & R & $\mathbf{R}^{2}$ & $\mathbf{F}$ & $\boldsymbol{\beta}$ & $\mathbf{T}$ & Sign. \\
\hline Kepekaan humor & - & - & - & 0,341 & 7,618 & 0,000 \\
Kreativitas & - & - & - & 0,357 & 6,052 & 0,000 \\
Kepekaan humor & 0,627 & 0,393 & 102,596 & - & - & 0,000 \\
dan kreativitas & & & & & & \\
\hline
\end{tabular}

Besarnya hubungan dapat dilihat pada tabel nilai $\mathrm{R}$, dimana terdapat hubungan yang positif antara kepekaan humor dengan kematangan emosi yaitu 
sebesar 0,393. Jika, dilihat dari nilai $\mathrm{R}^{2}$ pada hubungan antara kepekaan humor dan kreativitas dengan kematnagan emosi sebesar 0,393 artinya sumbangan kontribusi kepekaan humor dan kreativitas dengan kematangan emosi sebesar 39,3\%. Artinya semakin tinggi kepekaan humor maka semakin tinggi pula kematangan emosi.

\section{Simpulan}

Dari hasil penelitian, dapat disimpulkan bahwa terdapat hubungan positif antara kepekaan humor dan kreativitas dengan kematnagan emosi. Secara garis besar dapat dikatakan sumbangan kontribusi kepekaan humor dan kreativitas dengan kematangan emosi sebesar 39,3\% dan sisanya dipengaruhi oleh faktor lain. Feinberg (dalam Handayani, 2008: 15) menguraikan bahwa seseorang yang sudah mencapai kematangan emosi salah satunya adalah memilik kepekaan humor. Hartanti dan Rahaju (dalam Parman, 2013) menjelaskan dari kepekaan humor adalah suatu kemampuan individu menggunakan humor sebagai cara menyelesaikan masalah, keterampilan menciptakan humor, kemampuan menghargai atau menanggapi humor. Namun, dari hasil penelitian yang dilakukan di SMK Negeri 11 Semarang, tingkat kematangan siswa akan lebih dapat dipengaruhi dengan segala sesuatu yang berhubungan dengan kreativitas daripada dihubungkan dengan kepekaan humor. Alasannya adalah dalam kegiatan belajar di sekolah siswa lebih didominasi untuk mengasah daya kreativitas sehingga kreativitas sangat membantu dalam mengoptimalkan kematangan emosi. 


\section{DAFTAR PUSTAKA}

Agrippina, Yunika A. (2016). Hubungan Kematangan Emosi dan Kecenderungan Perilaku Cyberbullying Pada Dewasa Awal. Skripsi: Universitas Sanata Dharma Jurusan Psikologi. Diakses dari https://repository.usd.ac.id/6173/2/119114047 full.pdf pada 05 Juli 2019.

Ali, Mohammad., \& Mohammad Asrori. (2006). Psikologi Remaja (Perkembangan Peserta Didik). Jakarta: PT Bumi Aksara.

Chaplin, J, P. penerjemah Kartono Kartini. (2009). Kamus Lengkap Psikologi. Jakarta: PT Raja Grafindo Persada.

Guswani, A. M dan Fajar K. (2011). Perilaku Agresi Pada Mahasiswa Ditinjau Dari Kematangan Emosi. Jurnal Psikolgi Pitutur. 1(2). 88. Diakses dari https://jurnal.umk.ac.id/index.php/PSI/index pada 20 Mei 2019.

Handayani. (2008). Hubungan Antara Kematangan Emosi Dengan Agresifitas Remaja. Skripsi: Universitas Muhammadiyah Yogyakarta.

Hartanti. 2002. Peran Sense Of Humor Dan Dukungan Sosial Pada Tingkat Depresi Penderita Dewasa Pascastroke. Anima: Indonesia Jurnal Psikologi. 1792): 107 119. Diakses dari http://www.anima.ubaya.ac.id/class/openpdf.php?file=1358311879.pdf pada 08 Juni 2019.

Hurlock, B. Elizabeth. (2000). Psikologi Perkembangan Suatu Pendekatan Sepanjang Rentang Kehidupan. Jakarta: Erlangga.

Karim, M.Y, dkk. (2018). Kepekaan Terhadap Humor Berhubungan dengan Tingkat Kecemasan Mahasiswa Fakultas Kedokteran Saat Mengahadapi Ujian. Smart Medical Journal. 1(1).14-17. Diakses dari http://doi.org/10.13057/smj.v1i1.24182 pada 08 Juli 2019.

Munandar, Utami. (2002). Kreativitas \& Keberbakatan Strategi Mewujudkan Potensi Kreatif \& Bakat. Jakarta: PT Gramedia Pustaka Utama.

Muthohar, Idham Qodr. (2016). Pengaruh Sense Of Humor Dan Kematangan Emosi Terhadap Kepercayaan Anggota Di Himpunan Mahasiswa Islam Cabang Ciputat. Skripsi: Universitas Islam Negeri Syarif Hidyatullah Jakarta. 
Sugiyono. (2017). Metode Penelitian Pendidikan. Bandung: Alfabet.

Sternberg, R. J., (1999). Creativity Is A Decision dalam Costa, A. L., (Ed). Teaching For Intelligence. Arlington Heights, Illinois: Skylight Training and Publishing, Inc 